\title{
Performance Evaluation of Multipurpose Tree Species Integrated with Moisture Conservation Structures on Degraded Area Closure at Babille District, Ethiopia
}

\author{
Bira Cheneke*, Musa Abdella, Robe Elema \\ Oromia Agricultural Research Institute, Fedis Agricultural Research Center, Harar, Ethiopia \\ Email address: \\ birracheneke7@gmail.com (B. Cheneke) \\ ${ }^{*}$ Corresponding author \\ To cite this article: \\ Bira Cheneke, Musa Abdella, Robe Elema. Performance Evaluation of Multipurpose Tree Species Integrated with Moisture Conservation \\ Structures on Degraded Area Closure at Babille District, Ethiopia. Journal of Water Resources and Ocean Science. \\ Vol. 10, No. 1, 2021, pp. 1-8. doi: 10.11648/j.wros.20211001.11
}

Received: December 11, 2020; Accepted: January 15, 2021; Published: January 30, 2021

\begin{abstract}
Tree planting on degraded lands plays a key role in forest rehabilitation processes through afforestation and/or reforestation. Moisture conservation structures have significant impact on seedling survivals at degraded lands. The objectives of this study were to evaluate the effect of moisture conservation structures on seedling survival and growth performance of selected tree species. Field experiment was conducted for four (2016-2020) in degraded area closure at Babile District East Hararghe Zone, Ethiopia. The experimental design followed was the split plot design. The moisture conservation structures as main plot used were Soil level bund, Trench and normal pit (used as control). The tree species grown as subplots were Moringa oleifera, Melia azedarach, Grevillea robusta, Leuceana leucocephala and Sesbanea sesban. The five tree species were planted by using seedlings. The tree survival rate, plant height, diameter at breast height and root collar diameter of the five tree species were measured every three months in year after transplanting. The result shows that moisture conservation structures were significant in tree survival rate, plant height, and root collar diameter but not in tree diameter at breast height. Tree seedling height and root collar diameter grown in the Soil level bund were significantly higher than those grown in moisture conservation structures, trench and normal pit $(\mathrm{P} \leq 0.05)$. Survival rate and diameter at breast height grown in the Trench were significantly higher than those grown in moisture conservation structures, soil level bund and normal pit $(\mathrm{P} \leq 0.05)$. The survival rate of tree seedling was higher when grown in Trench than normal pit (control) $(\mathrm{P} \leq 0.05)$. The interaction of tree species seedlings and moisture conservation structures shows that those seedlings grown on moisture conservation structures were significantly thicker, taller and more survived than those grown on the normal pit (control) $(\mathrm{P} \leq 0.05)$. Based on the experiments, it is concluded that moisture conservation structures particularly the Trenches was considered as the most appropriate planting pit. Therefore, further demonstration of Trenches tree planting should be carried out.
\end{abstract}

Keywords: Conservation Structures, Trench, Soil Level Bund, Multipurpose Trees, Normal Pit, Survival Rate

\section{Introduction}

Land degradation in Ethiopia is the major problem due to a number of factors. One of the importance causes is the removal of forest and vegetation cover as result of increased population leading to high demand for forest products land for expanding agricultural activities [5]. In Ethiopia, rapid deforestation caused by an escalating demand for fuel wood and expansion of land for agriculture has brought an ever increasing pressure on native woodland species [12].
Consequently these areas are now characterized by loss of soil fertility and soil erosion problem. If no remedial action is taken, this will cause severe impact on agricultural productivity leading to energy poverty and environmental degradation. Eastern Ethiopia particularly, East Hararghe high land is well known by vegetation cover and most of the surrounding area is covered by forests comprising a rich mixture of woody species [1]. In spite of the importance of forest ecosystem to the livelihoods of the people in the area, the forest is dwindling from time to time due to high exploitation of woody and non-woody products. 
Forest plantation on degraded rangelands can play a key role in harmonizing long-term forest ecosystem rehabilitation process [14]. The process of forest ecosystem rehabilitation can be accelerated through human intervention like afforestation or/and reforestation with moisture stress tolerant tree seedling transplanting from nursery sites in dry land areas. Afforestation is the common approach of restoration on degraded land and biodiversity conservation, and ecoenvironmental improvement [4]. However, the vegetation establishment on degraded land is constrained by many factors in which the insufficient moisture availability listed as the top constraint [11]. The conserved and stored rain water supports flourishing plant growth and tree seedling survivals in dry areas [17]. These could be possible through in-situ rainwater harvesting devices which have hydrological functions as it modifies water flows and facilitating plant growth and improve vegetation cover [16]. This was enhanced by reducing velocity of runoff and the water is collected behind the structures. However, it only could be realized through well designed and improved soil and water conservation and harvesting devices [8].

Trees are known to bring about changes in edaphic, microclimatic, floral, faunal and other components of the eco-system through bio-recycling of mineral elements, environmental modifications (including thermal and moisture regime) and changes in floral and faunal composition [15]. Multipurpose tree species play a considerable role in addressing such multi- faceted demands in mixed crop-livestock production systems [3]. They have the ability to fit into farming systems to use as a source of manure, soil conservation, fuel wood, farm implements and others like shade and shelter [10]. Before introducing any species to a given agro ecology, there is always a need for a well conducted field trial for matching of the species to a particular site [12]. The most reliable information is based on trial planting in the proposed plantation area. The first trial should be species screening trial that will test the survival and early growth performance of the species in one to three years [7].

In the degraded lands closure of Babille District, particularly, around the study area, Farmers and government have been planting many tree seedlings species year after year but the survival of those seedlings are poor and variable as the area is mainly affected by moisture stress and soil fertility problems. The impact of in-field rainwater harvesting technique (IRWH) practices or moisture conservation structures on the number of planted seedling survival has so far scarcely been investigated. Again, the area has not been given much research attention and are still lacking regarding the title. Therefore, the objectives of this study were to evaluate the effect of moisture conservation structures on seedling survival and growth performance of trees under area closure of degraded land in Babille District and for the same agro ecologies.

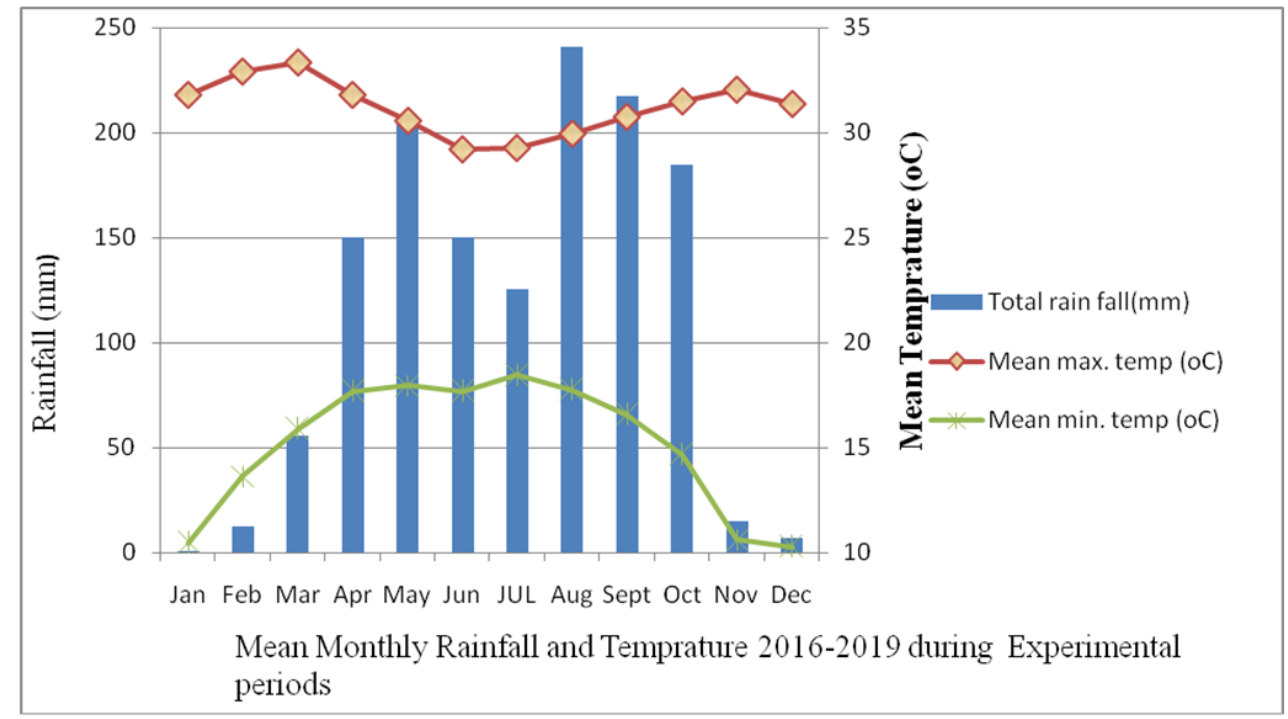

Figure 1. Mean monthly rainfall and temperature during experimental period based on meteorological data nearest to the study area.

\section{Materials and Methods}

\subsection{Description of the Study Site}

The experiment was conducted in Bishan Babille kebele; Babille District Eastern Oromia, Ethiopia (Figure 2). It is located is situated in eastern part of Ethiopia, about $593 \mathrm{~km}$ east of Addis Ababa, and $37 \mathrm{~km}$ east of Harar town. The altitude of the study area ranges from 950 to 2000 meters above sea level and latitude $9^{\circ} 21^{\prime}-9.35^{\circ}$ North and longitude $42^{\circ} 48^{\prime}-42.8^{\circ}$ east. The climate of the district is predominantly agro-pastoral type (low land) which is characterized by high temperature and the mean annual rainfall in the area ranges from 600 to $700 \mathrm{~mm}$ (Figure 1). The area characterized by very short rainy season of 3 to 4 months (single quarter of the year), with all its intermittent condition and erratic distribution. The mean annual temperature was $24^{\circ} \mathrm{C}$. The soil experimental site is clay loam in texture and medium in organic matter content and high in exchangeable potassium. The $\mathrm{pH}$ of the soil (7.94) is in the optimum range for growth of most plants. 


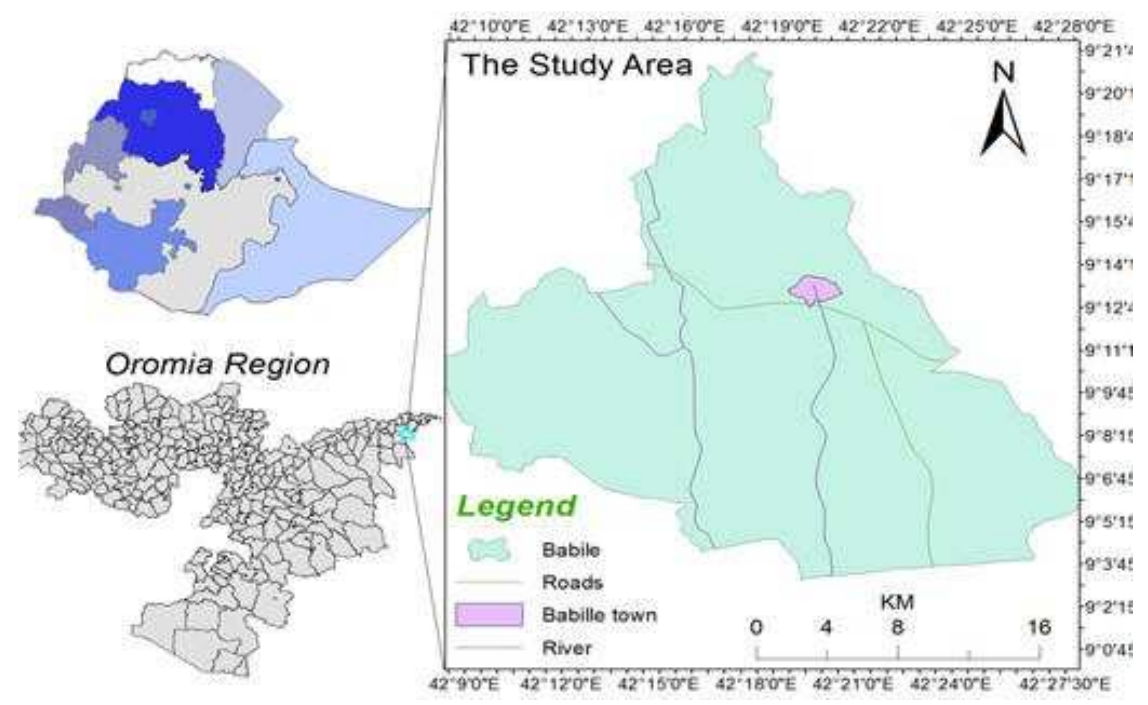

Figure 2. Map representing the study area (Babille district).

\subsection{Nursery and Field Management}

Seeds of the five tree species were obtained from Central Ethiopian Environment and Forestry Research Center. Seedlings were raised in polythene tubes of size $10 \mathrm{~cm}$ diameter and $15 \mathrm{~cm}$ length at Kile nursery site. The out planting site was cleared of bushes and the selected moisture conservation structures (planting methods) were prepared before planting the selected tree seedlings.

\subsection{Species Selection}

Five tree species were carefully selected for experimentation based on the preference of the community's multi-criteria decision approach taking into account indicators of ecological suitability, socio-economical functions, protection functions and root characteristics.

\subsubsection{Grevillea Robusta}

G. robusta is from Proteaceae family with medium-sized to tall tree up to $30 \mathrm{~m}$ high, usually less than $10 \mathrm{~m}$ in Ethiopia. It is a very successful Australian tree planted and widely used in dry, moist and wet WeynaDega and Dega agro climatic zones, $0-3,000 \mathrm{~m}$. It is used as firewood, charcoal, timber (furniture), poles, fodder (leaves), bee forage, shade, ornamental, soil conservation and windbreak.

\subsubsection{Moringa Oleifera}

Introduced to Ethiopia long ago and now naturalized in many parts of GamoGofa and in the Rift Valley and tried elsewhere. Requires well-drained soils with a high water table, but is drought resistant. Occurs at low altitudes in Dry and Moist Kolia agro climatic zones, $500-1,600 \mathrm{~m}$. It is used as Food 'young leaves, young fruit), medicine, fodder (leaves, fruit), bee forage, soil conservation, shade, windbreak, live fence, boundary marker, fibres, spice (young roots), oil (seeds), water purification (seeds).

\subsubsection{Melia Azedarach}

Grows in most soils, both acidic and saline, in Bereha and
Dry, Moist and Wet Kolia and Weyna Dega agro climatic zones, $0-2,400 \mathrm{~m}$. It grows in most soils, both acidic and saline, and is fairly drought resistant. It is used as Firewood, poles, posts, timber (tool handles), medicine (bark), bee forage, ornamental, shade, windbreak

\subsubsection{Sesbania Sesban}

One o f many useful African Sesbania spp. which survive water logging and fix nitrogen. It is found at the margin of fresh-water lakes and seasonal ponds. Some types tolerate acid and saline soils. Easy to establish even in dry eroded soil. It performs well in Moist and Wet Kolia and WeynaDega agro climatic zones. It is used as Firewood, poles, fodder (leaves), mulch, soil improvement, soil conservation, nitrogen fixation, shade (young coffee), fibres (young stems), soap (leaves).

\subsubsection{Leucaena Leucocephala}

An evergreen shrub or tree $5-20 \mathrm{~m}$, depending on the variety, medium leafy canopy, develops a deep tap-root even as a seedling. It is widely introduced in the tropics over the last 100 years, reaching Africa in 1950. It is grows best in humid Bereha and Moist and Wet Kolia agro climatic zones between 0 and $1,600 \mathrm{~m}$ altitude in full sunlight on welldrained neutral or calcareous soil. It is used as firewood, charcoal, poles, timber (from giant types), fodder (leaves, shoots), bee forage, green manure, soil conservation, soil improvement, nitrogen fixation, ornamental, live fence.

\subsection{Moisture Conserving Structures (MCSs)}

The effective MCSs which are familiar in the rehabilitation of degraded land were adopted for the experiment. According to the specification and design of the structures we used were as follows.

\subsubsection{Trench (TR)}

Are rectangular and deep pits constructed along the contours. The technical standards constructed and design we 
follow was; Size of the trench: 1.5 length $\mathrm{x} 0.4 \mathrm{~m} \mathrm{x}$ width $\mathrm{x}$ $0.5 \mathrm{~m}$ depth (downside); Trenches were provided with a small and low tie in the middle to regulate water flow $(15 \mathrm{~cm}$ width); Trees were not planted in the middle of the trench but in front of it; Plantation pit $40 \mathrm{~cm}$ depth $\mathrm{x} 40 \mathrm{~cm} \times$ width.

\subsubsection{Soil Level Bund (SLB)}

Are earth embankments constructed across the slope of the ditch on their upslope side and the earth material excavated thrown down slope. Dimension: 3 m length $x 1.1$ width $x 0.5$ $\mathrm{m}$ depth, Planting pit $40 \mathrm{~cm}$ depth $\mathrm{x} 40 \mathrm{~cm}$ width, was prepared in front of the square shaped water collection pit.

\subsubsection{Normal Pit (NP)}

Are circular and deep pits constructed along the contour.
Size: $40 \mathrm{~cm}$ depth $\mathrm{x} 40 \mathrm{~cm}$ width and used as control.

\subsection{Experimental Design and Layout}

Five tree species were established in three MCSs in a splitplot design with three replications. There were 15 treatments combination of two factors (Three moisture conservation structures $x$ Five Tree species $=15$ treatments) $($ Table 1). Each treatment combination was tried on 3 replications and thus a total of 45 plots (Three moisture conservation structures $x$ Five Tree species $x$ Three replication $=45$ plots $)$. Moisture conservation structures were the main plot factor in this experimental design, and tree species were randomly assigned to one of three moisture conservation structures. The tree species were planted by using seedlings.

Table 1. The treatments of the experiment.

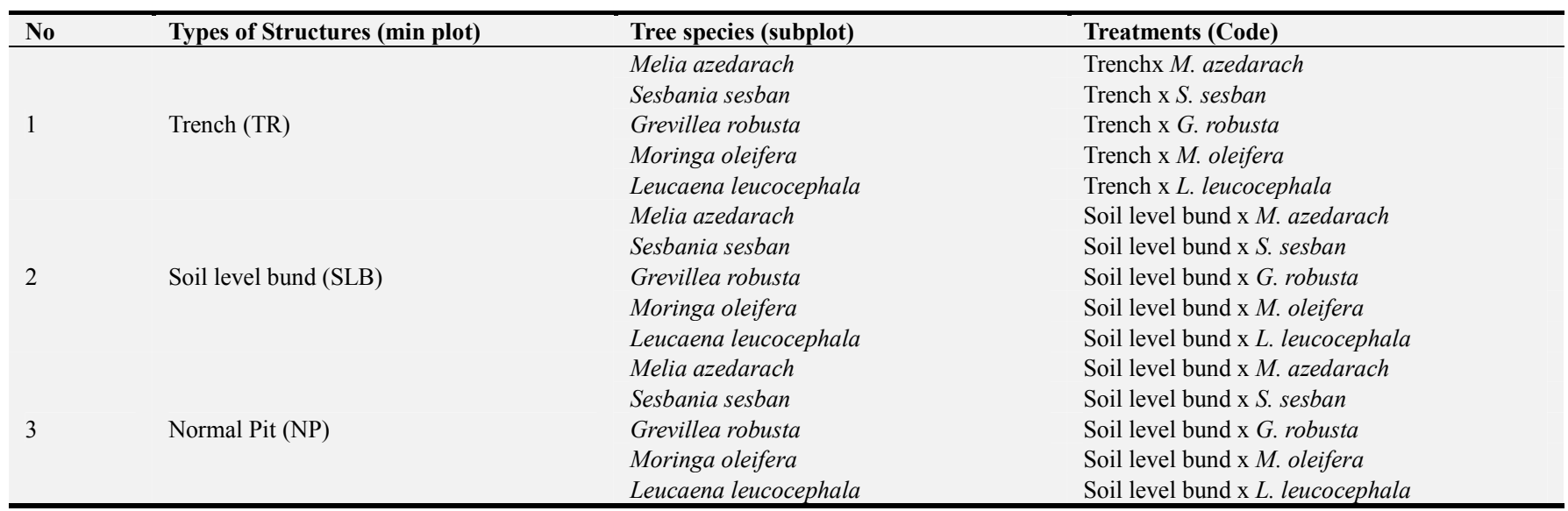

\subsection{Data Collection and Analysis}

The data collected were growth variables of tree species like tree survival rate in $\%$, Tree height $(\mathrm{H})$ in $\mathrm{cm}$; diameter at breast height $(\mathrm{DBH})$ in $\mathrm{cm}$ and Root collar diameter (RCD height) in $\mathrm{cm}$.

\subsection{Statistical Analysis}

Data were analyzed using Genstat software. Analysis of variance (ANOVA) was made to determine the significance of variation between the tree species and moisture conservation structures. Least Significant Difference (LSD) Test was used to compare mean values of various growth variables in each treatment at 5\% level of significance.

\section{Results and Discussion}

\subsection{Survival Rate of Tree Species}

The Analysis of variance revealed that the interaction of tree species survival with planting methods was found to be insignificant $(\mathrm{P}>0.05)$, in all, trench, level soil bund and normal pit at all four years of experimental period at the study area. But highly significant variations among tree species in survival rate $(\mathrm{P}<0.05)$ was recorded at all four years of age. The tree survival rate decreased from while passing through different growth intervals from first year to fourth year in all evaluated moisture conservation structures (Table 2). Survival rate decreased significantly with moisture conservation structures at different intervals of growth within year. At fourth year after establishment, the survival rate was maximum $(63.13 \%)$ first in Trench and decreased to $56.73 \%$ during fourth year. This finding also support [6] that interaction of tree/shrubs survival with planting methods was found to be insignificant $(\mathrm{P}>0.05)$ at one, two and three years of age after transplanting. The Trench recorded highest survival rate $(56.73 \%)$ followed by control $(56.4 \%)$ and the lowest were recorded for soil level bund $(56 \%)$ after four years after transplanting. The tree survival rate decreased significantly with the tree species at different year intervals. At fourth year the higher survival rate $(60.12 \%)$ were noticed due to Moringa oleifera followed by Melia azedarach and Leuceana leucocephala. The lowest survival rate was recorded for Grevillea robusta followed by Sesbania sesban. Similarly, at first, second, and third years after treatment there were corresponding decrease in survival rate for tree species. In overall interaction i.e. moisture conservation structures and tree species trench with Moringa oleifera, Melia azedarach, Leuceanea leucocephala and sesbanea sesban showed that, consistent higher in survival rate from first to fourth year. However, lowest the survival rate was recorded at fourth and third years compared to other fist and 
second years after establishment.

Table 2. Effect of moisture structures on survival rate of tree species within different years intervals.

\begin{tabular}{|c|c|c|c|c|}
\hline \multirow{2}{*}{$\begin{array}{l}\text { Treatments } \\
\text { Min plots (Structures) }\end{array}$} & \multicolumn{2}{|c|}{ Survival rate (\%) } & \multirow[b]{2}{*}{ Year III } & \multirow[b]{2}{*}{ Year IV } \\
\hline & Year I & Year II & & \\
\hline Trench (TR) & $63.13^{\mathrm{a}}$ & $58.48^{\mathrm{a}}$ & 57.13 & 56.73 \\
\hline Normal Pit (NP) & $57.93^{\mathrm{b}}$ & $53.00^{\mathrm{b}}$ & 58.28 & 56.4 \\
\hline Soil level bund (SLB) & $57.13^{\mathrm{b}}$ & $52.40^{\mathrm{b}}$ & 57.93 & 56 \\
\hline $\operatorname{LSD}(0.05)$ & 2.312 & 2.286 & NS & NS \\
\hline $\mathrm{CV}$ & 4.48 & 2.42 & 4.88 & 4.42 \\
\hline \multicolumn{5}{|l|}{ Sub plots (Trees) } \\
\hline Moringa oleifera & $67.89^{\mathrm{a}}$ & $64.11^{a}$ & $63.56^{\mathrm{a}}$ & $60.12^{\mathrm{a}}$ \\
\hline Melia azedarach & $64.78^{\mathrm{ab}}$ & $60.11^{a}$ & $58.56^{\mathrm{b}}$ & $57.07^{\mathrm{ab}}$ \\
\hline Sesbania sesban & $62.89^{\mathrm{bc}}$ & $62.67^{a}$ & $61.78^{\mathrm{a}}$ & $53.44^{\mathrm{c}}$ \\
\hline Leuceana leucocephala & $59.87^{\mathrm{c}}$ & $59.89^{\mathrm{b}}$ & $54.33^{\mathrm{b}}$ & $56.56^{\mathrm{bc}}$ \\
\hline Grevillea robusta & $42.11^{\mathrm{d}}$ & $42.11^{\mathrm{c}}$ & $42.00^{\mathrm{c}}$ & $37.11^{\mathrm{d}}$ \\
\hline $\operatorname{LSD}(0.05)$ & 3.486 & 3.833 & 4.061 & 3.402 \\
\hline $\mathrm{CV}$ & 7.89 & 7.44 & 7.06 & 5.97 \\
\hline \multicolumn{5}{|c|}{ Interactions (Structures x Trees species) } \\
\hline TR with $M$. oleifera & $75.00^{\mathrm{a}}$ & $58.33^{\mathrm{abc}}$ & $65.03^{\mathrm{a}}$ & $57.01^{\mathrm{a}}$ \\
\hline TR with $M$. azadarach & $75.01^{\mathrm{a}}$ & $55.33^{\mathrm{bcd}}$ & $60.33^{\mathrm{ab}}$ & $55.00^{\mathrm{bc}}$ \\
\hline NP with $M$. oleifera & $64.67^{\mathrm{b}}$ & $62.33^{\mathrm{ab}}$ & $58.33^{\mathrm{bc}}$ & $55.67^{\mathrm{a}}$ \\
\hline TR with L. leucocephala & $64.67^{\mathrm{b}}$ & $63.67^{\mathrm{a}}$ & $58.33^{\mathrm{bc}}$ & $57.00^{\mathrm{a}}$ \\
\hline SLB with M. oleifera & $64.33^{\mathrm{b}}$ & $63.00^{\mathrm{a}}$ & $57.00^{\mathrm{bcd}}$ & $55.67^{\mathrm{a}}$ \\
\hline NP with L. leucocephala & $62.67 b^{c}$ & $61.67^{\mathrm{ab}}$ & $56.33^{\mathrm{bcd}}$ & $55.67^{\mathrm{bc}}$ \\
\hline TR with $S$. sesban & $62.33^{\text {bed }}$ & $61.33^{\mathrm{abc}}$ & $55.33^{\mathrm{bcd}}$ & $48.67^{\mathrm{c}}$ \\
\hline SLB with $M$. azadarach & $62.00^{\mathrm{bcd}}$ & $61.33^{\mathrm{abc}}$ & $56.33^{\mathrm{cd}}$ & $54.67^{\mathrm{b}}$ \\
\hline NP with S. sesban & $60.67^{\mathrm{bcd}}$ & $55.67^{\mathrm{cd}}$ & $53.67^{\mathrm{cd}}$ & $49.33^{\mathrm{bc}}$ \\
\hline SLB with L. leucocephala & $60.67^{\mathrm{bcd}}$ & $60.00^{\mathrm{abcd}}$ & $55.33^{\mathrm{bcd}}$ & $54.33^{\mathrm{bc}}$ \\
\hline NP with $M$. azadarach & $57.00^{\mathrm{cd}}$ & $55.33^{\mathrm{d}}$ & $54.67^{\mathrm{cd}}$ & $51.03^{\mathrm{bc}}$ \\
\hline SLB with $S$. sesban & $56.67^{\mathrm{d}}$ & $55.33^{\mathrm{cd}}$ & $51.33^{\mathrm{d}}$ & $48.67^{\mathrm{bc}}$ \\
\hline NP with G. robusta & $44.33^{\mathrm{e}}$ & $47.00^{\text {ef }}$ & $37.33 \mathrm{e}$ & $35.33^{\mathrm{c}}$ \\
\hline SLB with G. robusta & $42.33^{\mathrm{e}}$ & $40.33^{\mathrm{fg}}$ & $35.67 \mathrm{e}$ & $32.67^{\mathrm{c}}$ \\
\hline TR with G. robusta & $39.67^{\mathrm{e}}$ & $38.67^{\mathrm{g}}$ & $32.33 \mathrm{e}$ & $35.67^{\mathrm{c}}$ \\
\hline $\operatorname{LSD}(0.05)$ & 6.038 & 7.665 & 5.893 & 6.215 \\
\hline $\mathrm{CV}$ & 9.58 & 7.67 & 5.61 & 12.87 \\
\hline
\end{tabular}

NB: TRs, trench (TRs), Soil level bund (SLB) and normal pit (NPs) as control. Similar letter in the row shows not significant difference and different letters indicate significance differences, NS: not significant difference between moisture structures (MSs) at $\mathrm{P} \leq 0.05$

This finding supports [2] who reported that the effects of moisture stress account for more than $87.9 \%$ in the death of tree seedlings. In similar ways, the moisture stress commonly limits growth, survival and distribution of tree seedlings [18]. These reduced soil moisture conditions may be viewed as a significant barrier to artificial reforestation [13].

\subsection{Plant Height}

The Analysis of variance revealed that tree height increased different year's interval. The main effect of moisture conservation structures was not significant, But highly significant variations among tree species in height (Table 3). The plant height is increased from $0.70 \mathrm{~m}$ to 1.89 $\mathrm{m}$ as recorded at different years interval i.e. first, second, third and fourth year after treatment but not significantly different. Plant height is increased due to moisture conservation measures at different intervals of growth within years. While at second, third and fourth years after treatment imposition there is a corresponding increase in plant height in all the treatments. The Soil level bund (SLB), recorded significantly highest plant height $(0.72 \mathrm{~m}, 1.02 \mathrm{~m}, 1.62 \mathrm{~m}$ and $1.25 \mathrm{~m}$ at first, second, third and fourth year, respectively) followed Trench (TR), with $1.53 \mathrm{~m}$ at third, after treatment and the lowest is recorded in control (NP) with $0.70 \mathrm{~m}, 0.99 \mathrm{~m}, 1.47 \mathrm{~m}$ and $1.57 \mathrm{~m}$ at first, second, third and fourth year after treatment respectively. Trees species at M. oleifera had a significant effect on plant height from first year $(0.91 \mathrm{~m})$ to fourth year $(1.89 \mathrm{~m})$ over the other treatments.

The interaction of soil level bund with $M$. oleifera, trench with $M$. oleifera and normal pit with $M$. oleifera had exhibited significant effects on plant height at all the intervals. Among combinations of soil moisture conservation measures and tree species interactions, the interaction between Soil level bund (SLB) with M. oleifera recorded significantly highest plant height at all the intervals (first year to fourth year) followed by trench with $M$. oleifera, and normal pit with $M$. oleifera. The finding is in line with the previously stated that the major limitations of plant height are soil nutrients and moisture availability within the rooting zone and a planted seedling's ability to access it [9]. 
Table 3. Effect of moisture structures on Tree height of tree species within different year intervals.

\begin{tabular}{|c|c|c|c|c|}
\hline \multirow{2}{*}{\begin{tabular}{|l} 
Treatments \\
Min plots (Structures)
\end{tabular}} & \multicolumn{2}{|c|}{ Plant height (m) } & \multirow[b]{2}{*}{ Year III } & \multirow[b]{2}{*}{ Year IV } \\
\hline & Year I & Year II & & \\
\hline Soil level bund (SLB) & 0.72 & 1.02 & 1.48 & 1.62 \\
\hline Trench (TR) & 0.7 & 1.01 & 1.53 & 1.59 \\
\hline Normal Pit (NP) & 0.7 & 0.99 & 1.47 & 1.57 \\
\hline $\operatorname{LSD}(0.05)$ & NS & NS & NS & NS \\
\hline $\mathrm{CV}$ & 9.37 & 7.49 & 13.64 & 7.01 \\
\hline \multicolumn{5}{|l|}{ Sub plots (Trees) } \\
\hline Moringa oleifera & $0.91^{a}$ & $1.32^{\mathrm{a}}$ & $1.80^{\mathrm{a}}$ & $1.89^{\mathrm{a}}$ \\
\hline Melia azedarach & $0.75^{b}$ & $1.02^{\mathrm{b}}$ & $1.48^{\mathrm{b}}$ & $1.58^{\mathrm{b}}$ \\
\hline Sesbania sesban & $0.67^{b c}$ & $0.98^{\mathrm{b}}$ & $1.43^{\mathrm{b}}$ & $1.53^{\mathrm{bc}}$ \\
\hline Leuceana leucocephala & $0.64^{\mathrm{c}}$ & $0.92^{\mathrm{bc}}$ & $1.41^{\mathrm{b}}$ & $1.51^{\mathrm{bc}}$ \\
\hline Grevillea robusta & $0.55^{\mathrm{d}}$ & $0.82^{\mathrm{c}}$ & $1.33^{\mathrm{b}}$ & $1.43^{\mathrm{c}}$ \\
\hline $\operatorname{LSD}(0.05)$ & 0.079 & 0.124 & 0.158 & 0.14 \\
\hline $\mathrm{CV}$ & 10.91 & 10.73 & 8.28 & 7.86 \\
\hline \multicolumn{5}{|c|}{ Interactions (Structures x Trees species) } \\
\hline SLB with $M$. oleifera & 0.9 & $1.37^{\mathrm{a}}$ & $1.85^{\mathrm{a}}$ & $1.63^{\mathrm{b}}$ \\
\hline TR with $M$. oleifera & 0.96 & $1.36^{\mathrm{a}}$ & $1.79^{\mathrm{a}}$ & $1.88^{\mathrm{a}}$ \\
\hline NP with $M$. oleifera & 0.88 & $1.23^{\mathrm{a}}$ & $1.77^{\mathrm{ab}}$ & $1.52^{\mathrm{bcd}}$ \\
\hline NP with M. azedarach & 0.77 & $1.03^{\mathrm{b}}$ & $1.51^{\mathrm{bc}}$ & $1.92^{\mathrm{a}}$ \\
\hline SLB with M. azedarach & 0.75 & $1.02^{\mathrm{b}}$ & $1.49^{\mathrm{cd}}$ & $1.91^{\mathrm{a}}$ \\
\hline TR with S. sesban & 0.71 & $1.00^{\mathrm{bc}}$ & $1.48^{\mathrm{cd}}$ & $1.48^{\mathrm{bcd}}$ \\
\hline NP with S. sesban & 0.67 & $0.96^{\mathrm{bc}}$ & $1.45^{\mathrm{cd}}$ & $1.53^{\mathrm{bcd}}$ \\
\hline SLB with $S$. sesban & 0.67 & $0.96^{\mathrm{bc}}$ & $1.44^{\text {cd }}$ & $1.54^{\mathrm{bcd}}$ \\
\hline TR with M. azedarach & 0.77 & $0.95^{\mathrm{bc}}$ & $1.44^{\mathrm{cd}}$ & $1.52^{\mathrm{bcd}}$ \\
\hline TR with L. leucocephala & 0.63 & $0.94^{\mathrm{bc}}$ & $1.43^{\mathrm{cd}}$ & $1.54^{\mathrm{bcd}}$ \\
\hline SLB with L. leucocephala & 0.66 & $0.92^{\mathrm{bc}}$ & $1.43^{\mathrm{cd}}$ & $1.51^{\mathrm{bcd}}$ \\
\hline NP with L. leucocephala & 0.62 & $0.91^{\mathrm{bc}}$ & $1.41^{\mathrm{cd}}$ & $1.61^{\mathrm{bc}}$ \\
\hline NP with G. robusta & 0.57 & $0.85^{\mathrm{bc}}$ & $1.39^{\mathrm{cd}}$ & $1.34^{\mathrm{d}}$ \\
\hline SLB with $G$. robusta & 0.55 & $0.83^{\mathrm{c}}$ & $1.28^{\mathrm{cd}}$ & $1.59^{\mathrm{bcd}}$ \\
\hline TR with $G$. robusta & 0.52 & $0.81^{\mathrm{c}}$ & $1.24^{\mathrm{d}}$ & $1.37^{\mathrm{cd}}$ \\
\hline $\operatorname{LSD}(0.05)$ & NS & 0.229 & 0.238 & 0.102 \\
\hline $\mathrm{CV}$ & 12.87 & 12.87 & 10.22 & 9.301 \\
\hline
\end{tabular}

Note: Trench (TRs), Soil level bund (SLB) and normal pit (NPs) as control. Similar letter in the row shows not significant difference and different letters indicate significance differences, NS: not significant difference between moisture structures (MSs) at $\mathrm{P} \leq 0.05$

\subsection{Diameter at breast height (DBH)}

Analysis of variance reveals that there was no significant difference in diameter at breast height $(\mathrm{cm})$ of seedlings with respect to moisture conservation structures during the second and third years. The diameter at breast height (DBH) increased from $1.130 \mathrm{~cm}$ to $5.48 \mathrm{~cm}$ while passing through different intervals. DBH from second to fourth year after treatment is presented in (Table 4). Tree DBH increased significantly due to different moisture conservation structures at stages of growth in fourth year. At fourth year, the DBH of $5.19 \mathrm{~cm}$ was noticed in TR (Trenches). The Trenches (TR) recorded significantly higher $\mathrm{DBH}(5.19 \mathrm{~cm})$ followed by Soil level bund $(4.33 \mathrm{~cm})$ and the lowest was recorded in control (4.11 at fourth year). DBH increased significantly with the tree of $M$. oleifera at different intervals. At fourth year maximum DBH $(4.83 \mathrm{~cm})$ was noticed at $M$. oleifera tree. The overall interaction, effect of moisture conservation methods and tree species showed that SLBM (Soil level bund with $M$. azedarach recorded higher DBH and it has increased from second $(1.130 \mathrm{~cm})$ to fourth year $(5.48 \mathrm{~cm})$ as compared to normal pit with $M$. oleifera $(1.13 \mathrm{~cm}$ at first year and 5.47 at fourth) and lowest was recorded in control $(3.05 \mathrm{~cm}$ at fourth year).

Table 4. Effect of moisture structures on Tree height of tree species within different year intervals.

\begin{tabular}{|c|c|c|c|}
\hline \multirow{2}{*}{$\begin{array}{l}\text { Treatments } \\
\text { Min plots (Structures) }\end{array}$} & \multicolumn{3}{|c|}{ Diameter at breast height $(\mathrm{cm})$} \\
\hline & Year II & Year III & Year IV \\
\hline Trenches (TR) & 0.18 & 1.24 & $5.19^{a}$ \\
\hline Soil level bund (SLB) & 0.26 & 1.27 & $4.33^{b}$ \\
\hline Normal Pit (NP) & 0.24 & 1.24 & $4.11^{\mathrm{b}}$ \\
\hline $\operatorname{LSD}(0.05)$ & NS & NS & 1.121 \\
\hline $\mathrm{CV}$ & 5.2 & 5.69 & 42.64 \\
\hline \multicolumn{4}{|l|}{ Sub plots (Trees) } \\
\hline Moringa oleifera & $1.244^{\mathrm{a}}$ & $1.310^{\mathrm{a}}$ & $4.83^{\mathrm{a}}$ \\
\hline Melia azedarach & $1.130^{\mathrm{b}}$ & $1.230^{\mathrm{b}}$ & $3.47^{\mathrm{b}}$ \\
\hline Sesbania sesban & $1.130^{\mathrm{b}}$ & $1.230^{\mathrm{b}}$ & $3.22^{\mathrm{b}}$ \\
\hline Leuceana leucocephala & $1.130^{\mathrm{b}}$ & $1.230^{\mathrm{b}}$ & $3.93^{\mathrm{ab}}$ \\
\hline Grevillea robusta & $1.130^{\mathrm{b}}$ & $1.230^{\mathrm{b}}$ & $4.05^{\mathrm{ab}}$ \\
\hline LSD (0.05) & 0.189 & 0.059 & 1.09 \\
\hline $\mathrm{CV}$ & 5.5 & 4.96 & 26.05 \\
\hline \multicolumn{4}{|c|}{ Interactions (Structures $\mathrm{x}$ Trees species) } \\
\hline SLB with $M$. azedarach & $1.130^{\mathrm{b}}$ & $1.230^{\mathrm{b}}$ & $5.48^{\mathrm{a}}$ \\
\hline NP with $M$. oleifera & $1.120^{\mathrm{ab}}$ & $1.213^{\mathrm{b}}$ & $5.48^{\mathrm{a}}$ \\
\hline SLB with $M$. oleifera & $1.301^{\mathrm{a}}$ & $1.413^{\mathrm{a}}$ & $4.74^{\mathrm{ab}}$ \\
\hline NP with $M$. azadarach & $1.130^{\mathrm{b}}$ & $1.230^{\mathrm{b}}$ & $4.74^{\mathrm{ab}}$ \\
\hline NP with L. leucocephala & $1.130^{\mathrm{b}}$ & $1.230^{\mathrm{b}}$ & $4.38^{\mathrm{ab}}$ \\
\hline TR with $G$. robusta & $1.130^{\mathrm{b}}$ & $1.230^{\mathrm{b}}$ & $4.28^{\mathrm{ab}}$ \\
\hline TR with $M$. oleifera & $1.230^{\mathrm{ab}}$ & $1.303^{\mathrm{ab}}$ & $4.25^{\mathrm{ab}}$ \\
\hline NP with $G$. robusta & $1.130^{\mathrm{b}}$ & $1.230^{\mathrm{b}}$ & $4.24^{\mathrm{ab}}$ \\
\hline SLB with L. leucocephala & $1.130^{\mathrm{b}}$ & $1.230^{\mathrm{b}}$ & $3.75^{\mathrm{ab}}$ \\
\hline SLB with $G$. robusta & $1.130^{\mathrm{b}}$ & $1.230^{\mathrm{b}}$ & $3.61^{\mathrm{ab}}$ \\
\hline TR with L. leucocephala & $1.130^{\mathrm{b}}$ & $1.230^{\mathrm{b}}$ & $3.60^{\mathrm{ab}}$ \\
\hline NP with $S$. sesban & $1.130^{\mathrm{b}}$ & $1.230^{\mathrm{b}}$ & $3.05^{\mathrm{b}}$ \\
\hline SLB with $S$. sesban & $1.130^{\mathrm{b}}$ & $1.230^{\mathrm{b}}$ & $2.85^{\mathrm{b}}$ \\
\hline TR with $S$. sesban & $1.130^{\mathrm{b}}$ & $1.230^{\mathrm{b}}$ & $2.84^{b}$ \\
\hline TR with $M$. azadarach & $1.130^{\mathrm{b}}$ & $1.230^{\mathrm{b}}$ & $2.60^{\mathrm{b}}$ \\
\hline $\operatorname{LSD}(0.05)$ & 0.103 & 0.104 & 1.712 \\
\hline $\mathrm{CV}$ & 89.14 & 87.14 & 29.204 \\
\hline
\end{tabular}

Note: Trench (TRs), Soil level bund (SLB) and Normal Pit (NPs) as control. Similar letter in the row shows not significant difference and different letters indicate significance differences, NS: not significant difference between moisture structures (MSs) at $\mathrm{P} \leq 0.05$

\subsection{Root Collar Diameter}

Analysis of variance reveals that there was no significant difference in $\mathrm{RCD}(\mathrm{cm})$ of seedlings with respect to moisture conservation structures during the first and second years. The plant collar diameter increased from $1.94 \mathrm{~cm}$ to $8.93 \mathrm{~cm}$ through two growth stages from third to fourth year after treatment (Table 5). Plant collar diameter increased significantly with moisture conservation measures at different intervals of growth. At third year the plant collar diameter $(2.09 \mathrm{~cm})$ increased significantly in SLB (Soil level bund). While at fourth year after treatment there was a corresponding increase in plant collar diameter in the treatment. The Soil level bund (SLB) recorded significantly higher collar diameter $(1.94 \mathrm{~cm}$ and $8.93 \mathrm{~cm}$ at third and fourth year after treatment) followed by Trenches (TR) (1.95 $\mathrm{cm}$ and $5.28 \mathrm{~cm}$ at third and fourth year) and the lowest was recorded in control $(1.68 \mathrm{~cm}, 1.93 \mathrm{~cm}, 1.94 \mathrm{~cm}$ and $6.56 \mathrm{~cm}$ at first, second, third and fourth year after treatment respectively). 
Variations were also recorded among the tree species tested. Trees species at $M$. oleifera had a significant effect on collar diameter from I year $(2.34 \mathrm{~cm})$ to fourth year $(7.52 \mathrm{~cm})$ over the other treatments. Trees species at $M$. azedarach had significantly increased the collar diameter from first year (1.73 $\mathrm{cm})$ to fourth year after treatment $(5.61 \mathrm{~cm})$ as compared to control. The interaction of SLB with $M$. olifera, TR with $M$. oliefera, NP with $M$. oleifera, and TR with $M$. azedarach exhibited significant effects on plant collar diameter at all the interval. In case of main plot treatment and sub plot treatment interactions, interaction between Soil level bund (SLB) with $M$. oleifera SLB with $M$. oleifera $(2.69 \mathrm{~cm})$ recorded significantly higher plant collar diameter at all the intervals (first to thirdyearafter treatment) followed by TR with $M$. oliefera, NP with M. oleifera, and TR with M. azedarach.

Table 5. Effect of moisture structures on collar diameter (cm) of tree species within different year intervals.

\begin{tabular}{|c|c|c|c|c|}
\hline \multirow{2}{*}{$\begin{array}{l}\text { Treatments } \\
\text { Min plots (Structures) }\end{array}$} & \multicolumn{4}{|c|}{ Collar Diameter (cm) } \\
\hline & Year I & Year II & Year III & Year IV \\
\hline Soil level bund (SLB) & 1.82 & 1.92 & $2.09^{\mathrm{a}}$ & $5.83^{\mathrm{a}}$ \\
\hline Trench (TR) & 1.72 & 2.08 & $1.95^{\mathrm{ab}}$ & $5.28^{\mathrm{a}}$ \\
\hline Normal Pit (NP) & 1.68 & 1.93 & $1.94^{\mathrm{b}}$ & $6.59^{\mathrm{b}}$ \\
\hline $\operatorname{LSD}(0.05)$ & NS & NS & 0.145 & 3.067 \\
\hline $\mathrm{CV}$ & 8.92 & 8.26 & 22.68 & 51.71 \\
\hline \multicolumn{5}{|l|}{ Sub plots (Trees) } \\
\hline Moringa oleifera & $2.34^{a}$ & $2.57^{\mathrm{a}}$ & $2.57^{\mathrm{a}}$ & $7.52^{\mathrm{a}}$ \\
\hline Melia azedarach & $1.73^{\mathrm{b}}$ & $1.97^{\mathrm{b}}$ & $1.97^{\mathrm{b}}$ & $5.61^{\mathrm{b}}$ \\
\hline Sesbania sesban & $1.63^{\mathrm{bc}}$ & $1.79^{\mathrm{bc}}$ & $1.80^{\mathrm{bc}}$ & $5.82^{\mathrm{b}}$ \\
\hline Leuceana leucocephala & $1.53^{\mathrm{c}}$ & $1.80^{\mathrm{bc}}$ & $1.88^{\mathrm{bc}}$ & $4.64^{b}$ \\
\hline Grevillea robusta & $1.47^{\mathrm{c}}$ & $1.72^{\mathrm{c}}$ & $1.75^{\mathrm{c}}$ & $5.91^{\mathrm{b}}$ \\
\hline LSD (0.05) & 0.188 & 0.216 & 0.187 & 1.84 \\
\hline $\mathrm{CV}$ & 10.56 & 10.95 & 15.73 & 20.94 \\
\hline \multicolumn{5}{|c|}{ Interactions (Structures x Trees species) } \\
\hline SLB with $M$. oleifera & $2.37^{\mathrm{a}}$ & $2.60^{\mathrm{ab}}$ & $2.60^{\mathrm{a}}$ & 4.82 \\
\hline TR with $M$. oleifera & $2.45^{\mathrm{a}}$ & $2.69^{\mathrm{a}}$ & $2.42^{\mathrm{a}}$ & 6.91 \\
\hline NP with $M$ oleifera & $2.20^{\mathrm{a}}$ & $2.42^{\mathrm{ab}}$ & $2.68^{\mathrm{a}}$ & 6.5 \\
\hline NP with $M$. azadarach & $1.55^{\mathrm{c}}$ & $1.84^{\mathrm{c}}$ & $1.84^{\mathrm{c}}$ & 6.73 \\
\hline SLB with $M$. azadarach & $1.55^{\mathrm{c}}$ & $1.78^{\mathrm{c}}$ & $1.67^{\mathrm{c}}$ & 8.93 \\
\hline TR with $S$. sesban & $1.65^{\mathrm{b}}$ & $1.85^{\mathrm{c}}$ & $2.28^{\mathrm{b}}$ & 4.6 \\
\hline NP with $S$. sesban & $1.56^{\mathrm{c}}$ & $1.82^{\mathrm{c}}$ & $1.79^{c}$ & 6.21 \\
\hline SLB with $S$. sesban & $1.67^{\mathrm{b}}$ & $1.71^{\mathrm{c}}$ & $1.82^{\mathrm{c}}$ & 4.79 \\
\hline TR with $M$. azadarach & $2.07^{\mathrm{b}}$ & $2.29^{\mathrm{b}}$ & $1.94^{\mathrm{c}}$ & 5.01 \\
\hline TR with L. leucocephala & $1.51^{\mathrm{c}}$ & $1.84^{\mathrm{c}}$ & $1.84^{\mathrm{c}}$ & 4.73 \\
\hline SLB with L. leucocephala & $1.53^{\mathrm{c}}$ & $1.82^{\mathrm{c}}$ & $1.75^{\mathrm{c}}$ & 4.6 \\
\hline NP with L. leucocephala & $1.55^{\mathrm{c}}$ & $1.75^{\mathrm{c}}$ & $1.88^{\mathrm{c}}$ & 7.13 \\
\hline NP with $G$. robusta & $1.52^{\mathrm{c}}$ & $1.79^{c}$ & $1.82^{\mathrm{c}}$ & 6.20 \\
\hline SLB with G. robusta & $1.46^{\mathrm{c}}$ & $1.67^{\mathrm{c}}$ & $1.71^{\mathrm{c}}$ & 5.41 \\
\hline TR with G. robusta & $1.43^{\mathrm{c}}$ & $1.71^{\mathrm{c}}$ & $1.89^{c}$ & 6.14 \\
\hline LSD $(0.05)$ & 0.366 & 0.364 & 0.369 & NS \\
\hline $\mathrm{CV}$ & 12.87 & 10.96 & 10.36 & 32.72 \\
\hline
\end{tabular}

Note: Trench (TRs), Soil level bund (SLB) and normal pit (NPs) as control. Similar letter in the row shows not significant difference and different letters indicate significance differences, NS: not significant difference between moisture structures (MSs) at $\mathrm{P} \leq 0.05$

\section{Conclusion and Recommendation}

The moisture conservation methods have a potential to forma chief component in the rehabilitation of degraded land and forest establishment. Particularly, moisture conservation structure devices are an important way in facilitating favorable conditions for plant growth as well as tree seedling survival in moisture stress areas. Four years after establishment, the study results revealed that moisture conservation structures (MCSs) are verified as effective structures in producing well survived and grown trees species. The growth parameters of the tree species planted in the soil level bund (SLB) is better than trench (TR) in height and root color diameter. Tree species planted in trench (TR) were also the most appropriate planting pit in surviving plant than normal pit (NP). The interaction effect was significant; strongly indicating it was influenced by the combined treatments (tree species and moisture conservation structures). The moisture conservation structures shows great potential in increasing tree survival and growth performance due to helping to harvest rainwater and protecting them. However, the use moisture conserving structures (MCSs) for L. leucocephala and G. robusta tree species didn't affect their growth performance and survivals. So, expanding moisture conserving structures (MCSs) is the most appropriate afforestation method particularly for degraded area. More studies needed on slope, type and runoff storage capacity before transplanting the trees. More elaborative studies are required with more representative locations and in different soil and agro ecology.

\section{Acknowledgements}

The authors are thankful to Oromia Agricultural Research Institute for financial support and Fadis Agricultural Research center for provision of facility for research work. We also thankful to Alemneh Setagn and Birhanu Legesse for their participation in concerning of the trail's management.

\section{References}

[1] Abebe Yadessa, Diriba Bekere and Taye Bekele. 2000. Growth performance of different multipurpose trees and shrub species at Bako, Western Oromia. pp 177-186. In: Proceeding of the Fifth Conference of the Ethiopian Society of Soil Science. Addis Ababa, Ethiopia, 30-31 March 2000, Ethiopian Society of Soil Science, Addis Ababa, Ethiopia.

[2] Abraham M (2014). Factors Affecting Survival of Tree Seedlings in the Dry lands of Northern Ethiopia. 4 (16): 2224-3186.

[3] Betre Alemu, Tekeligm Mamo, Alemayehu Zewdie and Ebrahim Ahmed. 2000. Promising multipurpose tree species and their response to land form on highland Vertisols at ChefeDonsa, central highlands of Ethiopia. pp. 145-155. In: Proceeding of the Fifth Conference of the Ethiopian Society of Soil Science. Addis Ababa, Ethiopia, 30-31 March 2000, Ethiopian Society of Soil Science, Addis Ababa, Ethiopia.

[4] Boers TM, Ben-Asher J (1982). A review of rain water harvesting. Agric. Water Manage. 5 (2): 145-158.

[5] Cao S (2011). Impact of China's large-scale ecological restoration program on the environment and society in arid and semiarid areas of China: achievements, problems, synthesis, and applications. Crit. Rev. Environ. Sci. Technol. 41 (4): 317-335. 
[6] Daws MI, Mullins CE, Burslem DF, Paton SR, Dalling JW (2002). Topographic position affects the water regime in a semi deciduous tropical forest in Panama. Plant soil 238 (1): 79-89.

[7] Demel Teketel, 2001. Deforestation, wood famine, and environmental degradation in Ethiopia's highland Ecosystems: urgent need for action. Northeast African Studies, 8 (1): 5376.

[8] Demisachew Tadele, Awdenegest Moges and Mihret Dananto (2018). Impact evaluation on survival of tree seedling using selected in situ rainwater harvesting methods in Gerduba Watershed, Borana Zone, Ethiopia. Journal of Horticulture and Forestry 10 (4): 43-51.

[9] Desalegn Mamo, Eshetu Ararso, Alemayhu Diriba, Shimelis Dekeba, Dulo Hussen (2016). Early Survival Evaluation of Trees and Shrubs for Their Adaptability Planted Under Moisture Conservation Structures at HawiGudina District, West Hararghe Zone, Ethiopia. American Journal of Agriculture and Forestry 4 (6): 152-155.

[10] Eldridge, K., Davidson, J., Harwood, C. and G. van Wyk. 1994. Eucalyptus Domestication and Breeding. Clarendon Press, Oxford. 288p.

[11] Evans, J. 1996; plantation forestry in the tropics (2nd ed.). Oxford science publications. Clarendan press, Oxford.
[12] Gowing JW, Mahoo HF, Mzirai OB, Hatibu N (1999). Review of rainwater harvesting techniques and evidence for their use in semiarid Tanzania. Tanzania J. Agric. Sci. 2 (2).

[13] Grossnickle SC (2005). Importance of root growth in overcoming planting stress. New Forests 30 (2-3): 273-294.

[14] Gupta GN (1995). Rain-water management for tree planting in the Indian Desert. J. Arid Environ. 31 (2): 219-235.

[15] Hatibu N, Mahoo HF, Gowing JW, Kajiru GJ, Lazaro EA, Mzirai OB, Senkondo EM (2001). Rainwater harvesting for natural resources management: a planning guide for Tanzania. Regional L and Management Unit.

[16] Jha AK, Singh JS (1992). Restoration of degraded land: concepts and strategies. Rastogi Publication Meerut pp. 212-254.

[17] Kahsay Berhe, Giulia Conchedda and Mohammad A. Jabbar. 2001. Areas suitable for five leguminous trees and shrubs in Ethiopia: A digital data based analysis. Ethiopian Journal of Natural Resources (EJNR) 3 (1): 77-97.

[18] Li WQ, Liu XJ, Khan MA, Gul B (2008). Relationship between soil characteristics and halophytic vegetation in coastal region of North China. Pak. J. Bot. 40 (3): 1081-1090. 